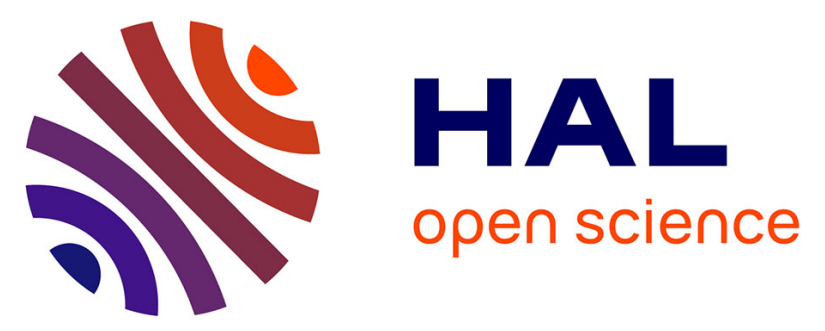

\title{
A general diastereoselective synthesis of highly functionalized ferrocenyl ambiphiles enabled on a large scale by electrochemical purification
}

Emmanuel Lerayer, Patrice Renaut, Julien Roger, Nadine Pirio, Hélène Cattey, Charles H. Devillers, Dominique Lucas, Jean-Cyrille Hierso

\section{To cite this version:}

Emmanuel Lerayer, Patrice Renaut, Julien Roger, Nadine Pirio, Hélène Cattey, et al.. A general diastereoselective synthesis of highly functionalized ferrocenyl ambiphiles enabled on a large scale by electrochemical purification. Chemical Communications, 2017, 53 (44), pp.6017-6020. $10.1039 / \mathrm{c} 7 \mathrm{cc} 02469 \mathrm{j}$. hal-03473696

\section{HAL Id: hal-03473696 https://hal.science/hal-03473696}

Submitted on 9 Dec 2021

HAL is a multi-disciplinary open access archive for the deposit and dissemination of scientific research documents, whether they are published or not. The documents may come from teaching and research institutions in France or abroad, or from public or private research centers.
L'archive ouverte pluridisciplinaire HAL, est destinée au dépôt et à la diffusion de documents scientifiques de niveau recherche, publiés ou non, émanant des établissements d'enseignement et de recherche français ou étrangers, des laboratoires publics ou privés. 


\title{
A general diastereoselective synthesis of highly functionalized ferrocenyl ambiphiles enabled at large scale by electrochemical purification
}

\author{
Emmanuel Lerayer, ${ }^{a}$ Patrice Renaut, ${ }^{a}$ Julien Roger, ${ }^{a}$ Nadine Pirio, ${ }^{a}$ Hélène Cattey,${ }^{a}$ Charles H. Devillers, ${ }^{* a}$ \\ Dominique Lucas $^{a}$ and Jean-Cyrille Hierso ${ }^{* a, b}$
}

\author{
${ }_{5}$ Received (in $\left.X X X, X X X\right)$ Xth $X X X X X X X X X 20 X X$, Accepted Xth $X X X X X X X X X 20 X X$ \\ DOI: 10.1039/b000000
}

\begin{abstract}
A general synthesis of highly functionalized ferrocenes, which includes (P, B)- and (N, B)-ambiphiles has been developed at multigram scale. Diastereoselective stepwise modification of 10 di-tert-butylated ferrocene included the unprecedented separation of electroactive species. Bulky alkyl groups on ferrocene insure planar chirality of ambiphiles and enforce closer proximity of antagonist Lewis functions.
\end{abstract}

15 Ambiphilic derivatives are molecular systems that combine electron donor and acceptor groups on a common platform. These compounds have prompted much recent interest and their study represents a very active field in main-group chemistry. ${ }^{1}$ Applications include their use as ligands for transition metals 20 towards uncommon coordination modes, ${ }^{2}$ and the activation and transfer of small molecules including $\mathrm{CO}_{2}$ and $\mathrm{H}_{2},{ }^{3}$ a reactivity which is usually associated to transition metals. The synthesis of a growing variety of $(\mathrm{P}, \mathrm{B})$ - and $(\mathrm{N}, \mathrm{B})$-ambiphiles is relating to modifications in the substitution pattern at Lewis functions, ${ }^{4}$ and 25 in the structure of supporting plateform. ${ }^{5}$ With respect to spacers, organic linkers are generally preferred and only a few metallocene-bridged phosphine-borane derivatives have been reported (representative examples are depicted in Figure 1).

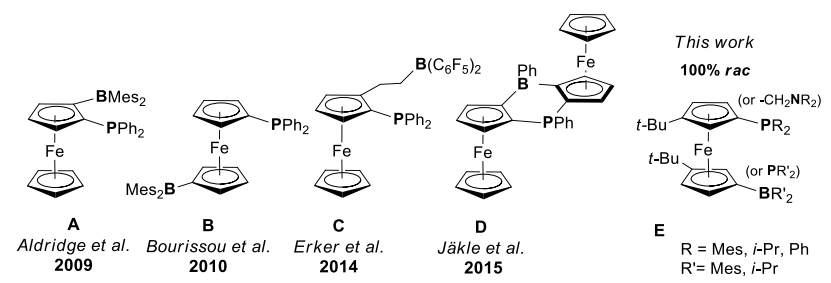

30 Figure 1 Representative ferrocene-bridged phosphine-borane ambiphiles.

Aldridge and Bourissou groups reported the preparation of $\mathrm{Ph}_{2} \mathrm{P}$ (1,2-ferrocenyl)-BMes2 A (Mes = 2,4,6-trimethylphenyl), ${ }^{6}$ and the position isomer $\mathrm{Ph}_{2} \mathrm{P}-(1,6$-ferrocenyl)-BMes $2 \quad$ B, respectively. ${ }^{7}$ Based on the ferrocene platform other cousin 35 structures were also reported $(\mathbf{C}$ and $\mathbf{D}) .^{8-9}$ The flexible phosphine-borane $\mathbf{B}$ and the related $o$-phenylene bridged system have been evaluated in rhodium-catalysed hydroformylation. ${ }^{7}$ This pioneering work highlighted the structuring potential of 1,1'ferrocene platform for (P, B)-pairs. Marinetti and Cantat used 40 afterwards ferrocene $\mathbf{B}$ as catalysts for the hydroboration of $\mathrm{CO}_{2 .}{ }^{10}$ Diaconescu et al. additionally exploited the ferrocene platform to yield heteroscorpionate ferrocenylphosphine borate compounds made from the synthesis of the ambiphilic precursor $\mathrm{Fc}\left(\mathrm{PPh}_{2}\right)\left(\mathrm{BOMe}_{2}\right)$ and $\mathrm{Li}$ chelated derivatives. ${ }^{11}$ In this context, 45 further extension of this class of ambiphiles is highly desirable. We address herein this challenging issue by introducing a greater modularity in substitution pattern at $\mathrm{P}$ and $\mathrm{B}$ atoms. Further functionalization at ferrocene introduces novel properties such as planar chirality and backbone steric control. Steric control 50 permits the $\mathrm{P}$...B distance and the rotational rigidity of the platform to be tuned. Our group had designed highly functionalized ferrocenyl polyphosphines incorporating di-tertbutylated and gem-dimethylated substitution. Such sterically controlled ligands were exploited in palladium-catalysed $\mathrm{C}-\mathrm{H}$ 55 bonds functionalization. ${ }^{12}$ We envisioned that ferrocenyl ambiphilic analogues could be developed by the incorporation of tert-butyl groups to the metallocene backbone (E, Figure 1). A general approach would allow extending the synthesis to new bifunctional analogues (N/B), ${ }^{13}(\mathrm{P} / \mathrm{N}),{ }^{14}$ and $\left(\mathrm{P} / \mathrm{P}^{\prime}\right) .{ }^{15}$ We report ${ }_{60}$ herein this method that we scaled-up at multigram scale by the electrochemical purification of the essential intermediate di-tertbutyl-dibromoferrocene. Ambiphiles of type $\mathbf{E}$ were prepared by sequential lithiation/electrophilic trapping from 1,1'-dibromo3,3'-di-tert-butyl-ferrocene $\mathbf{2 a}$ (Scheme 1). We found this 65 synthetic pathway to be more efficient than assembling from tertbutylated boryl cyclopentadienides, which is also feasible. ${ }^{16,17}$

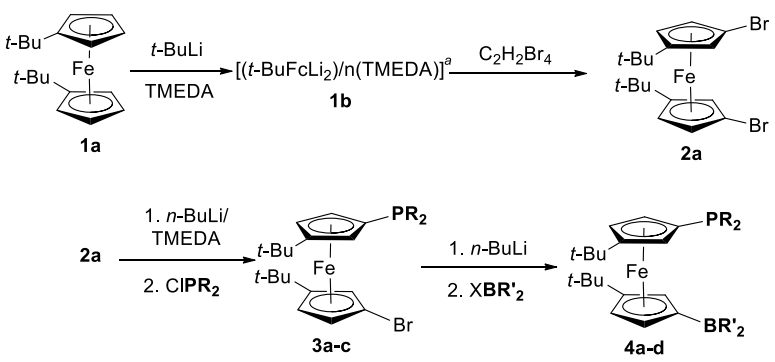

Scheme 1 Synthesis of tert-butylated ambiphiles 4a-d. ${ }^{a}$ In THF-d8 $\mathbf{1 b}$ appeared from ${ }^{1} \mathrm{H}$ NMR as $c a$. 1:1 adduct (see ESI), under other 70 conditions it was described as a 1:1.5 organolithium/TMEDA adduct. ${ }^{18 \mathrm{~b}}$

We patented the diastereoselective road for synthesizing 2a (Scheme 1) in yields up to $93 \%$ at the 1 mmol scale. ${ }^{18}$ Planar chiral (rac) 1,1'-di-tert-butyl-ferrocene $2 \mathbf{a}$ had been obtained by using an excess of 1,1,4,4-tetrabromoethane in $\mathrm{Et}_{2} \mathrm{O}$. We then 75 sought at establishing efficient procedures for the preparation of 
hybrid bifunctional ferrocenes $\mathbf{E}$ on a much larger scale. While the general method was found to be convenient at $1 \mathrm{mmol}$ scale, synthesis of $2 \mathbf{a}$ via the bromination of $c a .30 \mathrm{mmol}$ of dilithiatedTMEDA complex $\mathbf{1 b}$ showed repeatability troubles. We mainly 5 observed the presence in detrimental amounts of unreacted 1,1'di-tert-butyl-ferrocene 1a (up to $25 \mathrm{~mol} \%$ ) and monobrominated 1-bromo-3,3'-di-tert-butyl-ferrocene $\mathbf{2 b}$ (up to $28 \mathrm{~mol} \%$ ). The separation by chromatography of $\mathbf{1 a}, \mathbf{2 b}$ and $\mathbf{2 a}$ was found to be tedious because of similar retention times on the silica and 10 alumina we tested. We turned our attention to an oxidative purification of $\mathbf{2 a}$ from its mixture with $\mathbf{1 a}$ and $\mathbf{2 b}$. The purification of ferrocene derivatives mixture by chemical redox processes has been described. ${ }^{19}$ Chemical oxidative separation has been exploited with haloferrocenes $\mathrm{FcX}_{\mathrm{n}}(\mathrm{X}=\mathrm{I}, \mathrm{Br}, \mathrm{Cl}$ and $\mathrm{F}$, $15 \mathrm{n}=0$-2) using aqueous $\mathrm{FeCl}_{3}$. The aqueous phase contains then ferrocenium species whereas nonoxidized haloferrocenes remains in the organic phase. Several washings procedures are necessary, and the solvent volume used and the concentration of $\mathrm{FeCl}_{3}$ must be finely adjusted to avoid overoxidation of the targeted 20 haloferrocene and contamination by undesired ferrocene products. In our hands, chemical oxidation applied on large-scale amounts of ferrocenes (10-20 mmol) was unproductive because of the formation of persistent emulsion phases hampering facile phase separation. We thus imagined the development of a large25 Scale oxidative purification by electrosynthesis, ${ }^{20}$ to overcome the drawbacks associated with the use of chemical oxidant. An additional benefit is the control of the applied potential for tuning the accuracy of oxidative reactions. We achieved electrochemical oxidative purification of $\mathbf{2 a}$ by a selective oxidation of the 30 undesired $\mathbf{1 a}$ and $\mathbf{2 b}$ in the reaction mixture. These ferrocene side-products exhibit less positive oxidation potential due to their deficit in electron-withdrawing bromine atoms in comparison to 2a. Accordingly for $\mathbf{1 a}, \mathbf{2 b}$ and $\mathbf{2 a}$, we found $E_{1 / 2}=0.346,0.524$ and $0.682 \mathrm{~V} v$ s. SCE, respectively (Fig. 2, see also in ESI, Fig. S5 35 and Table S2). Under these conditions ones add $-0.400 \mathrm{~V}$ for $E_{1 / 2}$ values vs. $\mathrm{Fc}^{+} / \mathrm{Fc}$. As expected, the resulting oxidized ferrocenium species $\mathbf{1 a}^{+}$and $\mathbf{2} \mathbf{b}^{+}$have low solubility in organic solvents compared to $\mathbf{2 a}$.

A typical initial crude solid $\left(\mathrm{CS}_{0}, m=22.40 \mathrm{~g}\right)$ resulting from 40 large-scale synthesis of 2a starting with $29.9 \mathrm{mmol}$ of the dilithiated-TMEDA complex $\mathbf{1 b}$ contained 1, 2b and 2a in 24, 28 and $48 \mathrm{~mol} \%$ ratio, respectively (Fig. S1, Table S1, in ESI). $\mathrm{CS}_{0}$ was also contaminated with residual 1,1,4,4-tetrabromoethane $\left({ }^{1} \mathrm{H}\right.$ NMR in $\left.\mathrm{C}_{6} \mathrm{D}_{6}, \delta=5.08\right)$ and other side-products $(\delta=6.30)$ 45 assigned to trans-1,2-dibromoethene (Figure S2). These impurities are present in low amount and did not perturb the electrolytic process. Electrochemical purification of $\mathbf{2}$ was achieved on small scale of $\mathrm{CS}_{0}(\mathrm{ca} . m=150 \mathrm{mg}, 0.2 \mathrm{mmol})$ with $\mathrm{CH}_{3} \mathrm{CN}$ and $0.1 \mathrm{M}$ of tetraethylammonium tetrafluoroborate $50\left(\mathrm{TEABF}_{4}\right)$. To reach a satisfactory purity of $\mathbf{2 a}, E_{\text {app }}$ was applied at an intermediate value between the $E_{1 / 2}$ of $\mathbf{2 b}$ and $\mathbf{2 a}$ and allowed a complete transformation of remaining $\mathbf{1 a}$ and sideproduct $\mathbf{2 b}$ into $\mathbf{1}^{+}$and $\mathbf{2} \mathbf{b}^{+}$(Scheme 2). We first adjusted $E_{\text {app }}$ at $0.600 \mathrm{~V}$ for electrolysis. After reaction completion and solvent 55 removal from anodic compartment, $n$-pentane extraction allowed eliminating the insoluble $\mathbf{1 a}^{+}$and $\mathbf{2} \mathbf{b}^{+}$by filtration. Purity of $\mathbf{2 a}$ reached $90.6 \%$ with a contamination of $\mathbf{2 b}(9.4 \%$, molar ratio of ferrocenes); we did not detect 1a or supporting electrolyte.

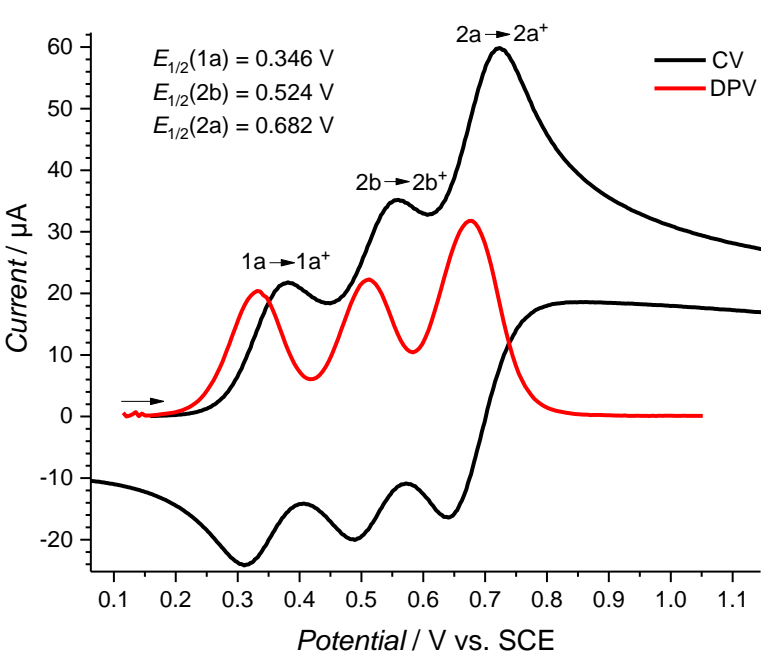

${ }_{60}$ Figure 2 Cyclic voltammetry $(\mathrm{CV})$ and differential pulse voltammetry (DPV) of a solution of $\mathrm{CS}_{0}(m=150 \mathrm{mg}),[2]=4.8 \times 10^{-3} \mathrm{M}$ in $\mathrm{CH}_{3} \mathrm{CN} 0.1$ $\mathrm{M} \mathrm{TEABF} 4 ;=100 \mathrm{mV} / \mathrm{s}$ and $10 \mathrm{mV} / \mathrm{s}$ for $\mathrm{CV}$ and $\mathrm{DPV}$, respectively, WE: Pt.

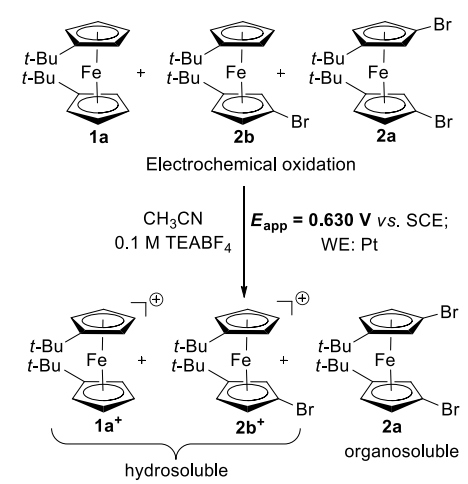

${ }_{65}$ Scheme 2 Electrochemical purification for $\mathbf{2 a}$.

We thus raised $E_{\text {app }}$ at $0.630 \mathrm{~V}$ to reach purity of $2 \mathrm{a}$ above 97\% (2b was present in less than 3\%, see Figure S2-S4, ESI). Electrolysis on $21.70 \mathrm{~g}$ of $\mathrm{CS}_{0}$ at $0.630 \mathrm{~V}\left([\mathbf{2 a}]=1.17 \times 10^{-1} \mathrm{M}\right)$ was worked-up similarly and the extract in $n$-pentane was 70 crystallized in $\mathrm{MeOH} .5 \mathrm{~g}$ of $\mathbf{2 a}$ were recovered with high purity (99 \%+). Compounds $\mathbf{2 b}$ and $\mathbf{1}$ were absent (Fig. S6-S8, ESI). We obtained a $75 \%$ yield for the global purification process considering the initial molar content of $\mathbf{2 a}$ in $\mathrm{CS}_{0}$. Our electrochemical oxidative process allowed obtaining $\mathbf{2 a}$ on a 75 multigram scale without tedious chromatography step. This general electrochemical purification is conceptually extendable to other mixtures of redox active compounds (metallocenes and others) with smart tuning of $E_{\text {app }}$ after careful CV analysis.

Formation of 2a in multigram amount with high purity was 80 critical to implement the modular synthesis of ambiphiles 4a-d via the synthesis of bromophosphinoferrocenes 3a-c (Scheme 3). These arylphosphino and alkylphosphino compounds are crystalline solids for which we report here X-ray structures. Various eclipsed and staggered conformations have been 85 obtained, in which the distance between the halogen and phosphine functions ranges from 4.4441(6) $\AA$ in $3 \mathrm{c}$ to $6.9484(15)$ $\AA$ in 3b ( vs 4.8723(5) $\AA$ for 3a, see Table S3). The presence of the tert-butyl groups hampers a trans-arrangement of the functions $\left(\mathrm{P}-\mathrm{Ct}-\mathrm{Br} \mathrm{ca} 180^{\circ}\right)$ in agreement with the predicted 90 conformational properties of substituted ferrocenes. ${ }^{21}$ 

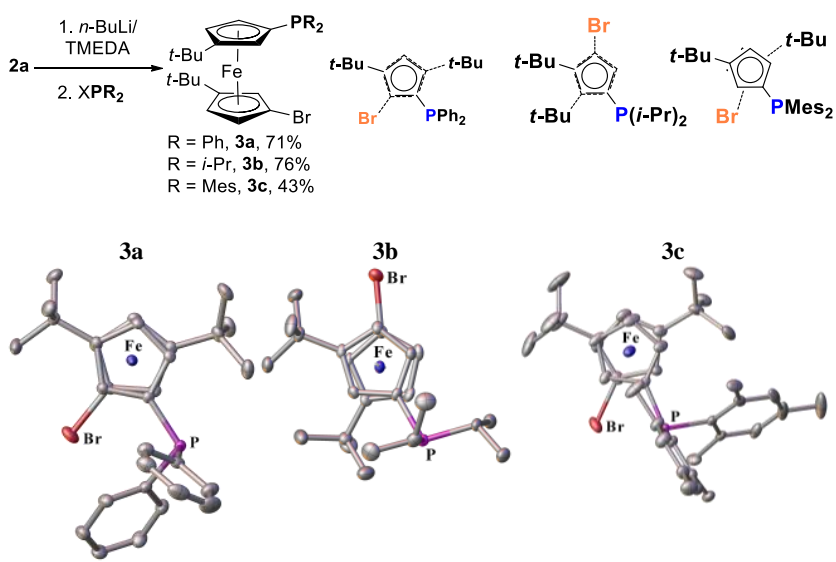

Scheme 3 Synthesis and conformation of monobromoferrocenes 3a-c.

${ }_{5} \mathrm{We}$ achieved the introduction of boryl functions on compounds 3a-c after $\mathrm{Br} / \mathrm{Li}$ exchange (Scheme 1), to give 4a-d in excellent yields (81-99\%) except for the hindered 4d (35\%). We characterized these ambiphiles in the solid state by X-ray diffraction studies (Figure 3) and in solution by NMR (Table 1).
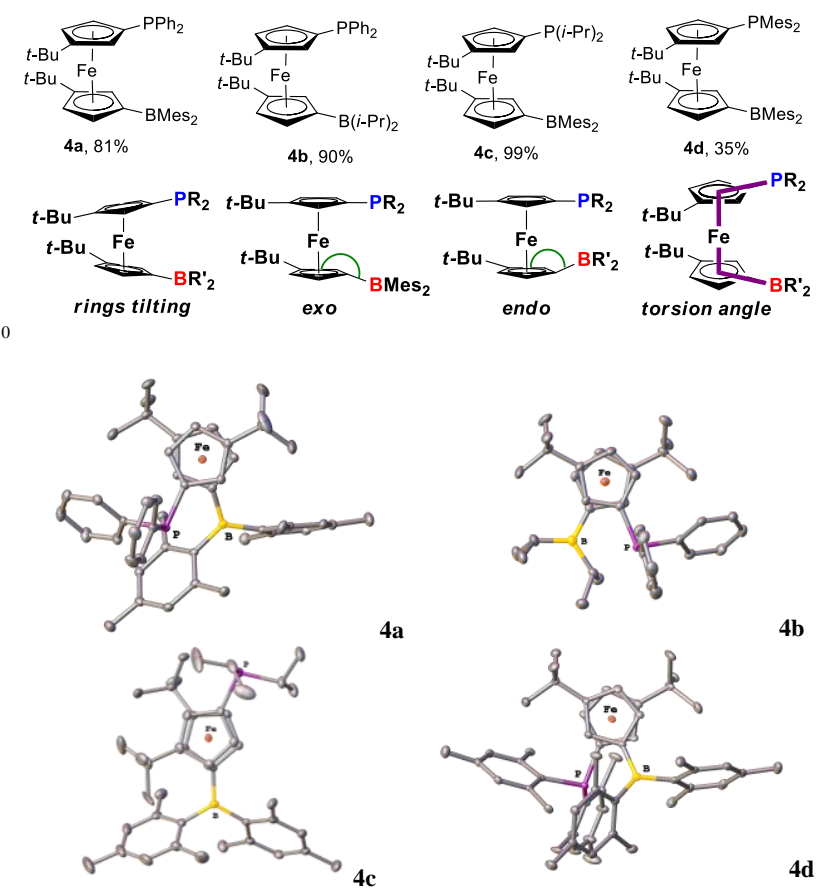

$4 a$
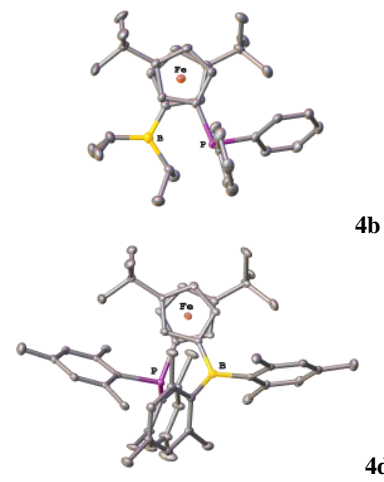

$4 \mathbf{b}$

4d

Figure 3 Ambiphiles 4a-d with typical ferrocene deformation and molecular structures according to XRD analysis.

This set of new planar chiral ambiphiles allows the comparative analysis of the geometric features provided by the ferrocene platform to the antagonist functions. We reported in Table 1 the P...B distances in relation with typical deformation of 20 functionalized ferrocenes. Bulky tert-butyl groups introduction in general favoured a closer proximity between the phosphine/borane pairs (comparatively the nonalkylated ambiphile $\mathbf{B}$ synthesized in Bourissou group showed $\mathrm{dP} . . \mathrm{B}=$ $4.876 \AA$ and dihedral angle $\mathrm{P} \ldots \mathrm{Ct}(1) \ldots \mathrm{Ct}(2) \ldots \mathrm{B}=57.80^{\circ}$ ). ${ }_{25}$ However, this was not the case for $\mathbf{4} \mathbf{c}$ in which is conserved the cisoid vicinal arrangement of $t$-Bu groups found for its bromide precursor 3b (Scheme 3). X-ray and solution NMR did not indicate $\mathrm{P} \rightarrow \mathrm{B}$ pairs closing for $\mathbf{4 a - d} .^{22}$ Mesityl groups on boron are clearly responsible for exo deviation of the $\mathrm{Cp}-\mathrm{B}$ bond. Less 30 sterically hindering isopropyl groups placed on boron atom conversely induces an endo deviation of the $\mathrm{Cp}-\mathrm{BR}_{2}$ bond of 6.6(4) ${ }^{\circ}$. It prompted also the shortest $\mathrm{P}$...B distance observed for this class of compounds, up to now, with a d P...B = 4.106 (3) A. Pyramidalisation of the boron atom was not observed, since the 35 sum of the three angle around the boron atom exceed $359^{\circ}$, excluding net $\mathrm{Fe} \rightarrow \mathrm{B}$ interactions. ${ }^{23}$

Table 1 NMR and X-ray features of 4a-d (P, B) ambiphiles.

\begin{tabular}{lcccc}
\hline & 4a & 4b & 4c & 4d \\
\hline${ }^{31} \mathrm{P}$ NMR $\delta(\mathrm{ppm})$ & -18.0 & -17.0 & -1.8 & -34.4 \\
${ }^{11} \mathrm{~B}$ NMR d $(\mathrm{ppm})$ & 80.1 & 79.0 & 80.0 & 80.0 \\
$\mathrm{~d}$ P...B $(\AA)$ & $4.6018(17)$ & $4.106(3)$ & $6.731(3)$ & $4.453(4)$ \\
ring tilting Cp $/ / \mathrm{Cp}\left(^{\circ}\right)$ & $7.75(6)$ & $1.98(9)$ & $2.58(13)$ & $5.3(2)$ \\
$\mathrm{Cp}-\mathrm{BR} 2$ exo/endo $\left(^{\circ}\right)$ & $13.65(14)$ & $6.6(4)$ & $5.8(3)$ & $11.9(7)$ \\
& exo & endo & exo & exo \\
& $42.37(5)$ & $52.99(8)$ & $150.20(5)$ & $46.04(10)$ \\
\hline
\end{tabular}

To further illustrate the potential of this synthetic 40 methodology we synthesized from 2a the bifunctional ferrocene hybrids (N, B) 7a-b, $(\mathrm{P}, \mathrm{N}) \mathbf{8}$, and $\left(\mathrm{P}, \mathrm{P}^{\prime}\right) \mathbf{9}$ (Scheme 4$) .{ }^{11} \mathrm{~B}(\delta 87-$ 88 ) in solution indicates open Lewis pairs configuration for $\mathbf{7 a - b}$ that is consistent with the solid state XRD refined for $\mathbf{7 b}$ in which $\mathrm{dN} . . \mathrm{B}=7.506(2) \AA$ with an angle $\mathrm{C}^{\mathrm{N}} \ldots \mathrm{Ct}(1) \ldots \mathrm{Ct}(2) \ldots \mathrm{B}=-$ $45145.19\left(6^{\circ}\right)$ similar to the configuration found for $\mathbf{4 c}$. However, we could determine rarely examined ${ }^{15} \mathrm{~N}$ NMR for both $6 \mathbf{a}(\delta-$ $327.1)$ and $7 \mathbf{a}(\delta-329.8)$, this resulted in a notable $\Delta \delta+2.7 \mathrm{ppm}$ low field shift that is consistent with net electron deshielding at $\mathrm{N}$ nuclei. This shift is remarkable since previously $\Delta \delta$ lesser than ${ }_{50} 0.7 \mathrm{ppm}$ have been found after the ortho-phosphination of the cousin tert-butylated bis-(diethylamino)methylferrocene $(\delta-$ $327.8)$ leading to $1,2-(\mathrm{P}, \mathrm{N})$-ferrocene derivatives $(\delta-327.2) .{ }^{24}$
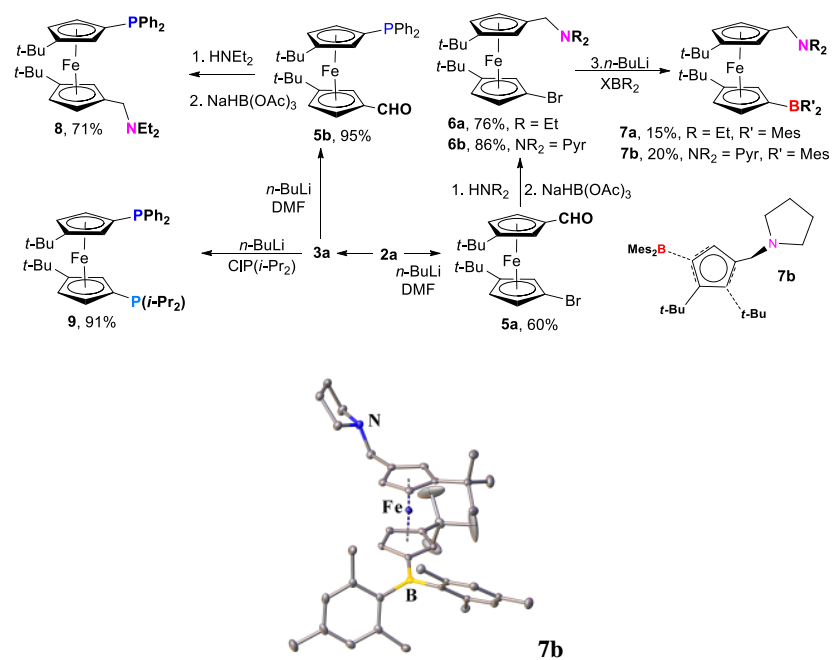

Scheme 4 Synthesis of tert-butylated 1,1'-planar chiral hybrids 7a-b, 8, 9.

55 Overall, we have delivered a robust, fully diastereoselective, method to provide new 1,1'-planar chiral (P, B)-ferrocene ambiphiles, for which scale up in multigram amount was secured by a smart electrochemical purification mode taking into profit 
ferrocene backbone redox properties. The extension to a new class of $(\mathrm{N}, \mathrm{B})$-ferrocene ambiphiles, and $(\mathrm{P}, \mathrm{P})$ - and $(\mathrm{P}, \mathrm{N})$ hybrids (potentially hemilabile compounds) illustrates the general interest of this synthetic chemistry. We currently investigate this 5 constrained new class of compounds, as well as other analogues, for their coordination as Lewis pair and intramolecular cooperative chemical reactivity.

The ANR (ANR-11-INTB-1008 MENOLEP), Région Bourgogne 10 (PARI CD2EA), the CNRS and the Université de Bourgogne supported this work. We warmly thank D. Bourissou, G. Bouhadir and G. Erker for fruitful discussions and S. Zouaghi for experimental work under E. L. guidance. C. H. D. thanks the CNRS for granting one year of "délégation CNRS" in 2015.

\section{${ }_{15}$ Notes and References}

${ }^{a}$ Institut de Chimie Moléculaire de l'Université de Bourgogne (ICMUB), Université de Bourgogne Franche-Comté (UMR 6302), 9, av. A. Savary, 21078 Dijon, France $;^{b}$ Institut Universitaire de France (IUF)

$\dagger$ CCDC numbers: 3a: 1532854, 3b: 1532855, 3c: 1532856, 4a: $20 \quad 1532857$, 4b: 1532859, 4c: 1532860, 4d: 1532861, 7b: 1532862.

1 (a) G. Bouhadir and D. Bourissou, Chem. Soc. Rev. 2016, 45, 1065; (b) H. Braunschweig, R. D. Dewhurst and A. Schneider, Chem. Rev. 2010, 110, 3924; (c) I. Kuzu, I. Krummenacher, J. Meyer, F. Armbruster and F. 25 Breher Dalton Trans., 2008, 5836; (d) M. A. Légaré, M. A. Courtemanche, E. Rochette and F.-G. Fontaine, Science, 2015, 349, 513. 2 (a) A. Amgoune and D. Bourissou, Chem. Commun., 2011, 47, 859; (b) F.-G. Fontaine, J. Boudreau and M. H. Thibault, Eur. J. Inorg. Chem., 2008, 5439; (c) H. Braunschweig and R. D. Dewhurst, Dalton Trans. 30 2011, 40, 549; (d) H. Kameo and H. Nakazawa, Chem.-Asian J., 2013, 8, 1720 ; (e) S. Bontemps, H. Gornitzka, G. Bouhadir, K. Miqueu and D. Bourissou, Angew. Chem., Int. Ed., 2006, 45, 1611; (f) S. Bontemps, G. Bouhadir, K. Miqueu and D. Bourissou, J. Am. Chem. Soc., 2006, 128, 12056; $(g)$ D. J. H. Emslie, J. M. Blackwell, J. F. Britten and L. E. 35 Harrington, Organometallics, 2006, 25, 2412; (h) S. R. Oakley, K. D. Parker, D. J. H. Emslie, I. Vargas-Baca, C. M. Robertson, L. E. Harrington and J. F. Britten, Organometallics, 2006, 25, 5835.

3 (a) G. C. Welch, R. R. San Juan, J. D. Masuda and D. W. Stephan, Science, 2006, 314, 1124; (b) D. W. Stephan and G. Erker, Angew.

${ }_{40}$ Chem., Int. Ed., 2010, 49, 46. (c) J. Boudreau, M.-A. Courtemanche, F.G. Fontaine, Chem. Commun. 2011, 47, 11131.

4 (a) M. A. Légaré, E. Rochette, J. Légaré Lavergne, N. Bouchard, F.-G. Fontaine, Chem. Commun. 2016, 52, 5387. (b) M.-A. Courtemanche, A. P. Pulis, E. Rochette, M. A. Légaré, D. Stephan, F.-G. Fontaine, Chem. 45 Commun. 2015, 51, 9797; (c) M.-A. Courtemanche, M.-A. Légaré, L. Maron, F.-G. Fontaine, J. Am. Chem. Soc. 2013, 135, 9326.

5 (a) P. Spies, R. Fröhlich, G. Kehr, G. Erker and S. Grimme, Chem.Eur. J., 2008, 14, 333-343; (b) B. E. Cowie and D. J. Emslie, , Chem.Eur. J., 2014, 20, 16899; (c) B. E. Cowie and D. J. Emslie, 50 Organometallics 2015, 34, 2737; (d) D. Schuhknecht, F. Ritter and M. E. Tauchert, Chem. Commun. 2016, 52, 11823.

6 I. R. Morgan, A. Di Paolo, D. Vidovic, I. A. Fallis and S. Aldridge, Chem. Commun., 2009, 7288.

7 M. W. P. Bebbington, S. Bontemps, G. Bouhadir, M. J. Hanton, R. P. 55 Tooze, H. van Rensburg and D. Bourissou, New J. Chem. 2010, 34, 1556. 8 J. Chen, D. A. Murillo Parra, R. A. Lalancette and F. Jäkle, Angew. Chem., Int. Ed. 2015, 54, 10202.

9 X. Wang, G. Kehr, C. G. Daniliuc and G. Erker, J. Am. Chem. Soc. 2014, 136, 3293.

6010 A. Tlili, A. Voituriez, A. Marinetti, P. Thuéry and T. Cantat, Chem. Commun. 2016, 52, 7553. Bis(pinacolato)boron (P, B)-ferrocene ambiphile was also reported in this work in a $18 \%$ yield $(0.09 \mathrm{mmol}, 45$ $\mathrm{mg}$ ), showing the difficulties generally associated with these syntheses.

11 M. Abubekerov, P. L. Diaconescu, Inorg. Chem. 2015, 54, 1778.

${ }_{65} 12$ (a) M. Beaupérin, R. Smaliy, H. Cattey, P. Meunier, J. Ou, P. H. Toy and J.-C. Hierso, Chem. Commun. 2014, 50, 9505; (b) D. Roy, S. Mom,
M. Beaupérin, H. Doucet and J.-C. Hierso, Angew. Chem., Int. Ed., 2010, 49, 6650; (c) D. Roy, S. Mom, D. Lucas, H. Cattey, J.-C. Hierso and H. Doucet, Chem.-Eur. J., 2011, 17, 6453.

7013 For 1,2-planar chiral amino-borane ferrocene-spaced ambiphiles and their relevant applications, see: (a) A. E. J. Broomsgrove, D. A. Addy, A. Di Paolo, I. R. Morgan, C. Bresner, V. Chislett, I. A. Fallis, A. L. Thompson, D. Vidovic and S. Aldridge, Inorg. Chem., 2010, 49, 157. (b) J. Chen, R. A. Lalancette and F. Jäkle, Organometallics 2013, 32, 5843; 75 (c) J. Chen, R. A. Lalancette and F. Jäkle, Chem.-Eur. J. 2014, 20, 9120. (d) Y.-L. Rao, T. Kusamoto, R. Sakamoto, H. Nishihara and S. Wang, Organometallics, 2014, 33, 1787.

14 (a) K. Skoch, I. Cisarova and P. Štěpnička, Organometallics 2015, 34, 1942; (b) R. C. J. Atkinson, V. C. Gibson and N. J. Long, Chem. Soc. 80 Rev. 2004, 33, 313; (c) P. Braunstein and F. Naud, Angew. Chem., Int. Ed. 2001, 40, 680

15 (a) P. Štěpnička, Ed.; Ferrocenes: Ligands, Materials and Biomolecules; John Wiley \& Sons Ltd: Chichester, 2008. Tert-butylated bifunctional (P, P)-ferrocene derivatives have recently met interest in 85 various catalytic applications: (b) J. Roger, S. Royer, H. Cattey, A. Savateev, R. V. Smaliy, A. N. Kostyuk and J.-C. Hierso, Eur. J. Inorg. Chem. 2017, 330; (c) M. Sophal, M. Platon, H. Cattey, H. J. Spencer, P. J. Low and J.-C. Hierso, Catal. Commun., 2014, 51, 10.

16 We recently synthesized 1,1'-diboryl metallocenes by assembly of 90 borylcyclopentadienide: E. Lerayer, P. Renaut, S. Brandès, H. Cattey, P. Fleurat-Lessard, G. Bouhadir, D. Bourissou, J.-C. Hierso, Inorg. Chem. 2017, 56, 1966.

17 By assembling functionalized cyclopentadienides, we obtained both "pseudo-rac" and "pseudo-meso" diastereomers of 4a (see ESI for 95 naming), in low yield as confirmed by XRD (unpublished results).

18 Patent application 12.13.2013: (a) E. Lerayer, P. Renaut, J. Roger, J.C Hierso, Fr. Demande, FR 3014871A1 20150619, 2015; (b) Synthesis of 2a was reported later in $1 \mathrm{~g}$ yield $(4 \mathrm{mmol}, 62 \%)$ following a similar way: A. R. Petrov, A. Derheim, J. Oetzel, M. Leibold, C. Bruhn, S. Scheerer, S. 100 Oßwald, R. F. Winter and U. Siemeling, Inorg. Chem. 2015, 54, 6657.

19 (a) L. Kurstan, L. Cunningham and D. R. McMillin, Polyhedron 1996, 15, 1673; (b) J. C. Goeltz and C. P. Kubiak Organometallics 2011, 30, 3908; (c) M. S. Inkpen, S. Du, M. Driver, T. Albrecht and N. J. Long, Dalton Trans. 2013, 42, 2813; (d) M. S. Inkpen, S. Du, M. Hildebrand, A. 105 J. P. White, N. M. Harrison, T. Albrecht and N. J. Long, Organometallics 2015, 34, 5461.

20 (a) C. H. Devillers, A. K. D. Dimé, H. Cattey and D. Lucas, Chem. Commun., 2011, 47, 1893; (b) G. de Robillard, O. Makni, H. Cattey, J. Andrieu and C. H. Devillers, Green Chem., 2015, 17, 4669; (c) S. Hebié, 110 A. K. D. Dimé, C. H. Devillers and D. Lucas, Chem.-Eur. J., 2015, 21, 8281.

21 C. A. Morrison, S. F. Bone, D. W. H. Rankin, H. E. Robertson, S. Parsons, R. A. Coxall, S. Fraser, J. A. S. Howell, P. C. Yates and N. Fey, Organometallics 2001, 20, 2309.

11522 Lewis character of the functions here does not overcome the geometric "frustration" provided by the ferrocene backbone used as spacer.

23 In ferrocenylboranes, the boron atom can be tilted towards the metal centre as the result of a delocalized through-space $\mathrm{Fe} \rightarrow \mathrm{B}$ interaction: (a) M. Scheibitz, M. Bolte, J. W. Bats, H.-W. Lerner, I. Nowik, R. H. Herber, 120 A. Krapp, M. Lein, M. C. Holthausen and M. Wagner, Chem.-Eur. J., 2005, 11, 584; (b) K. Venkatasubbaiah, L. N. Zakharov, W. S. Kassel, A. L. Rheingold and F. Jäkle, Angew. Chem., Int. Ed., 2005, 44, 5428-5433; (c) H. Braunschweig, I. Fernández, G. Frenking and T. Kupfer, Angew. Chem., Int. Ed., 2008, 47, 1951.

12524 F. Allouch, N. Dwadnia, N. V. Vologdin, Y. V. Svyaschenko, H. Cattey, M.-J. Penouilh, J. Roger, D. Naoufal, R. Ben Salem, N. Pirio and J.-C. Hierso, Organometallics 2015, 34, 5015. 